\title{
Pepper mottle virus Causing Disease in Chile Peppers in Southern New Mexico
}

\author{
G. Rodríguez-Alvarado, S. Fernandez-Pavia, R. Creamer, and C. Liddell, Department of Entomology, Plant \\ Pathology, and Weed Science, New Mexico State University, Las Cruces 88003
}

\begin{abstract}
Rodríguez-Alvarado, G., Fernandez-Pavia, S., Creamer, R., and Liddell, C. 2002. Pepper mottle virus causing disease in chile peppers in southern New Mexico. Plant Dis. 86:603-605.

The primary pepper producing areas of southern New Mexico were surveyed to identify the viruses causing severe disease in chile peppers over a 2-year period. The survey included weeds commonly found in and around pepper fields. Using indirect enzyme-linked immunosorbent assay (ELISA), Pepper mottle virus (PepMoV) was associated with plants showing mosaic and distortion of foliage and fruit deformation. PepMoV and Cucumber mosaic virus (CMV) were determined based on ELISA to be infecting chile peppers and weeds singly or in combination. Four perennial plant species were infected with PepMoV and CMV, including Solanum elaeagnifolium (silverleaf nightshade), Convolvulus arvensis (field bindweed), and Chamysuraces sp. (small groundcherry), which had not previously been identified as hosts for PepMoV. Some peppers and weeds surveyed were also infected at a lower level by several other plant viruses.
\end{abstract}

Additional keywords: ELISA, weed hosts

Viral diseases in field-grown pepper (Capsicum annuum L.) plants are a major concern for the pepper growers and the processing industry of southern New Mexico. Viruses infecting peppers are known to induce deformation of fruit and reduce yields $(1,3,6,10,11)$. Pepper growing areas in Arizona (6), California (1), Florida (11), Georgia (3), and Texas (10) have been affected by several viruses, including $\mathrm{Cu}$ cumber mosaic virus (CMV), Pepper mottle virus (PepMoV), Tobacco etch virus (TEV), Tomato spotted wilt virus (TSWV), Alfalfa mosaic virus (AlMV), and Potato virus $Y$ (PVY). Mixed infections of viruses infecting peppers are frequently reported. Abdalla et al. (1) detected seven viruses in single or mixed infections in California peppers, with CMV and PepMoV present in most plants. In northeastern Georgia, TEV and CMV were the predominant viruses in pepper fields (3). Thus, the distribution of viruses infecting peppers is variable and dependent on field location.

Corresponding author: R. Creamer

E-mail: creamer@taipan.nmsu.edu

Current address of G. Rodríguez-Alvarado and S. Fernandez-Pavia: Instituto de Investigaciones Agropecuarias y Forestales, Universidad Michoacana de San Nicolas Hidalgo, Ave. Acueducto y Tzintzunzan s/n, Morelia, Michoacán, Mexico 58240 .

Current address of C. Liddell: Paradigm Genetics, 104 Alexander Drive, Research Triangle Park, NC 27709.

Accepted for publication 18 January 2002.

Publication no. D-2002-0329-01R

(C) 2002 The American Phytopathological Society
Pepper plants with fruit deformation and uneven color, foliage distortion, mosaic, or mild mottle became a concern to producers and processors in southern New Mexico during 1992. The incidence of diseased plants appeared higher than in previous years with apparent differential symptom severity among varieties, and some pepper fields approaching $100 \%$ symptomatic plants. The foliage of plants in a given pepper field displayed a range of symptoms suggesting that more than one virus was infecting plants in the field. Nelson and Wheeler (6) reported one isolate of PepMoV from the Hatch area in New Mexico in 1978. Moreover, preliminary reports have indicated the presence of several other viruses infecting peppers in southern New Mexico (5).

This study documents the occurrence of PepMoV and CMV in field-grown pepper plants in southern New Mexico. Additionally, the presence of virus-infected perennial and annual weeds as hosts is confirmed.

\section{MATERIALS AND METHODS}

Virus isolates and mechanical transmission. CMV-S (subgroup II) and CMVSD2 (subgroup I) were previously described (8). TEV-Ox was obtained from W. Daugherty (Oregon State University, Corvallis), PVY was obtained from J. L. Sherwood (Oklahoma State University, Stillwater) (9), and PepMoV-Ca was obtained from J. A. Dodds (University of California, Riverside). PepMoV \#B725 was isolated from sacred datura (Datura innoxia Mill.), a perennial weed found near a pepper field north of Las Cruces, NM. Viruses were maintained in dried tobacco (Nicotiana tabacum L. 'Xanthi nc') tissue at $4^{\circ} \mathrm{C}$, and in greenhouse-grown tobacco plants. Viruses used as controls and selected field virus isolates (determined using enzyme-linked immunosorbent assay [ELISA]) were inoculated on seedlings of jimsonweed (D. stramonium L.), Chenopodium amaranticolor Willd., chile pepper (Capsicum annum L., cv. NM 64) and tobacco, by rubbing buffered $(0.02 \mathrm{M}$ potassium phosphate, $\mathrm{pH} 7.0,0.1 \%$ sodium thioglycolate, $0.3 \%$ sodium diethyldithiocarbamate) sap extract on 300-mesh Carborundum-dusted leaves.

Antisera. The PepMoV, PVY, and CMV (subgroup I) antisera was supplied by B. Falk (University of California, Davis), TEV antiserum was provided by Agdia, Inc. (Elkhart, IN), and the CMV (subgroup II) and AlMV antisera were obtained from American Type Culture Collection (Rockville, MD). The immunoglobulin (IgG) fraction from each antiserum was prepared using an Acti-Disk separation and purification cartridge (FMC, Rockland, ME). CMV subgroup I and II antisera were combined for serological tests. Selected pepper and weed samples collected in 1992 were sent to R. Jordan, USDA, Beltsville, MD for confirmation of PepMoV infection using monoclonal antibody ELISA.

Collection of pepper and weed samples. Plant samples were collected from 37 pepper farms primarily from the Deming, Las Cruces, and Hatch areas of southern New Mexico during 1992 and 1993. The pepper samples included leaves from young shoots with or without distinct symptoms of viral infection. Samples from common weeds were collected within areas bordering pepper fields and in nearby irrigation ditches. Weed samples were leaves with or without symptoms. Samples were stored at $4^{\circ} \mathrm{C}$ for 1 or 2 days prior to serological testing.

Sera cross-absorption. Antisera were cross-absorbed with healthy plant proteins using a modification of Ball et al. (2). Healthy plant leaf tissue $(100 \mathrm{mg})$ was ground in $10 \mathrm{ml}$ of phosphate-buffered saline (PBS) (0.1 M, pH 7.4), and centrifuged at $12,000 \times g$ for $1 \mathrm{~min}$. The supernatant was collected and $20 \mathrm{mg} \mathrm{IgG}$ was added to $1 \mathrm{ml}$, and incubated at room temperature for 1 to $2 \mathrm{~h}$. After centrifugation at $12,000 \times g$ for $1 \mathrm{~min}$, the mixture was diluted in $10 \mathrm{ml}$ of PBS plus $0.05 \%$ Tween $20,2 \%$ polyvinylpyrolidone 40,000 and $0.2 \%$ ovalbumin.

Indirect ELISA. Indirect plate-trapped ELISA (4) was used to detect viruses in plant samples. Each sample was tested 
twice. Leaf samples were ground in coating buffer $(0.05 \mathrm{M}$ carbonate, $0.02 \%$ sodium azide, $\mathrm{pH}$ 9.6) at 1:10 (wt/vol) and clarified by centrifugation at $12,000 \times g$ for $1 \mathrm{~min}$. The antigen was further diluted in coating buffer to $1: 10(\mathrm{vol} / \mathrm{vol})$ for PepMoV detection, and 1:1,000 ( $\mathrm{vol} / \mathrm{vol})$ for CMV, PVY, and TEV at $200 \mu \mathrm{l} /$ well and incubated at $4{ }^{\circ} \mathrm{C}$ overnight. After washing the plate, $200 \mu$ l of cross-absorbed IgGs were added per well and plates were incubated at $4{ }^{\circ} \mathrm{C}$ overnight. Plates were washed and alkaline phosphataseconjugated goat anti-rabbit IgG (Sigma, St. Louis, MO) was added at a $1 / 10,000$ dilution and incubated $2 \mathrm{~h}$ at $37^{\circ} \mathrm{C}$. $p$ Nitrophenyl phosphate $(200 \mu \mathrm{l} /$ well $)$ was added at $1 \mathrm{mg} / \mathrm{ml}$ and incubated at room temperature for 30 to $60 \mathrm{~min}$ for color development. Readings of reactions were carried out after $1 \mathrm{~h}$ at $405 \mathrm{~nm}$ in an EL312e Microplate Bio-Kinetics Reader (Bio-Tek Instruments, Inc.). Samples were considered positive when absorbance readings $\left(A_{405}\right)$ of sample wells were greater than three times the mean value of three healthy controls. This relationship was determined by ELISA sensitivity assays of chile infected with CMV, PVY, $\mathrm{PeMoV}$, or TEV that was maintained in the greenhouse.

Table 1. Occurrence of Cucumber mosaic virus (CMV) and Pepper mottle virus (PepMoV) in pepper samples collected in southern New Mexico during 1992 and 1993

\begin{tabular}{|c|c|c|c|c|c|}
\hline \multirow{2}{*}{$\begin{array}{l}\text { Locations where plants } \\
\text { were collected }\end{array}$} & \multirow[b]{2}{*}{ Year } & \multirow{2}{*}{$\begin{array}{l}\text { Number of } \\
\text { plants assayed }\end{array}$} & \multicolumn{3}{|c|}{ Number of plants infected with virus } \\
\hline & & & CMV & PepMoV & CMV + PepMoV \\
\hline \multirow[t]{2}{*}{ Deming } & 1992 & 60 & 0 & 36 & 2 \\
\hline & 1993 & 234 & 0 & 119 & 1 \\
\hline \multirow[t]{2}{*}{ Las Cruces, Vado } & 1992 & 52 & 4 & 4 & 27 \\
\hline & 1993 & 54 & 0 & 35 & 0 \\
\hline \multirow[t]{2}{*}{ Hatch, Rincon, Garfield } & 1992 & 85 & 2 & 8 & 1 \\
\hline & 1993 & 198 & 1 & 65 & 1 \\
\hline Hobbes & 1993 & 2 & 0 & 1 & 0 \\
\hline
\end{tabular}

Table 2. Occurrence of Cucumber mosaic virus (CMV)and Pepper mottle virus (PeMoV) in weed samples collected in southern New Mexico during 1992 and 1993

\begin{tabular}{lccccc}
\hline & & \multirow{2}{*}{$\begin{array}{l}\text { Number of } \\
\text { Weed species }\end{array}$} & \multicolumn{2}{c}{ Number of plants infected with virus } \\
\cline { 5 - 7 } Solanum elaeagnifolium Cav. & 1992 & 77 & 13 & 2 & 34 \\
\multirow{2}{*}{ Chamysuraces sp. } & 1993 & 123 & 4 & 27 & 51 \\
& 1992 & 5 & 0 & 0 & 5 \\
Datura innoxia Mill. & 1993 & 28 & 0 & 18 & 0 \\
& 1992 & 1 & 0 & 1 & 0 \\
Convolvulus arvensis L. & 1993 & 4 & 1 & 3 & 0 \\
& 1992 & 31 & 2 & 1 & 24 \\
Physalis wrightii Gray & 1993 & 53 & 0 & 23 & 14 \\
& 1992 & 12 & 0 & 0 & 12 \\
& 1993 & 2 & 0 & 2 & 0 \\
\hline
\end{tabular}

Table 3. Occurrence of Pepper mottle virus and Cucumber mosaic virus in plant samples collected in the Deming, NM area during 1993

\begin{tabular}{lcccccc}
\hline & \multicolumn{6}{c}{ Number infected/number tested } \\
\cline { 2 - 7 } Plant assayed & April & May & June & July & August & October \\
\hline Solanum elaeagnifolium Cav. & $59 / 59$ & $6 / 6$ & $0 / 0$ & $6 / 11$ & $0 / 0$ & $0 / 24$ \\
Convolvulus arvensis L. & $33 / 37$ & $6 / 6$ & $0 / 0$ & $0 / 0$ & $0 / 0$ & $0 / 0$ \\
Chamysuraces sp. & $1 / 11$ & $13 / 13$ & $0 / 0$ & $4 / 4$ & $0 / 0$ & $0 / 0$ \\
Pepper & $0 / 0$ & $0 / 0$ & $0 / 29$ & $18 / 75$ & $48 / 52$ & $55 / 77$ \\
\hline
\end{tabular}

Gray), were infected with PepMoV and/or CMV using ELISA (Table 2) and exhibited typical symptoms on indicator hosts (data not shown). These plants are commonly found in and near pepper fields in southern New Mexico. D. innoxia was found only in fence rows, while small Chamysuraces sp. plants were found only in irrigation ditches. S. elaeagnifolium and C. arvensis plants, were extensively sampled because these plants were ubiquitous in their distribution and have the highest populations in the areas sampled. Several plant species collected included mesquite (Prosopsis glandulosa Torr.), lambsquarters (Chenopodium album L.), saltbush (Atriplex sp.), whorled milk weed (Asclepias subverticillata (Gray) Vail), and Russian thistle (Salsola tragus Torner ex L.), were not infected.

D. meteloides Dunal, a perennial, has been described as the main overwintering host for PepMoV in Arizona (7), while $D$. metel L. and D. stramonium are not susceptible to this virus (6). In this study, PepMoV infected several D. innoxia plants near pepper fields and in three other perennial plants, S. elaeagnifolium, Chamysuraces sp., and $C$. arvensis. These perennials may serve as overwintering sources of PepMoV in southern New Mexico and as overwintering habitat for the aphid vectors of the virus. Several species of aphids, including Myzus persicae Sulz., transmit PepMoV in a nonpersistent manner (7).

During April and May of 1993, samples collected from actively growing weeds had a high incidence of PepMoV and CMV (Table 3). This suggests that the source of virus inoculum was already present when the peppers germinated during those months. The varying incidence of virusinfected plants among pepper farms suggests that those severely affected might be nearer to the virus inoculum source and/or that PepMoV is endemic in perennial plants in those areas. Seed transmission of PepMoV has not been documented (7).

When selected ELISA-positive samples were tested for virus infection using indicator species, PepMoV produced a mild mottle on tobacco plants, whereas CMV or a mixture of CMV plus PepMoV produced an obvious mosaic on tobacco plants. CMV produced mosaic in D. stramonium and local lesions in Chenopodium amaranticolor. The PepMoV isolates from southern New Mexico induced no symptoms in these two hosts, which was similar to the responses of the PepMoV isolate described previously from Hatch, NM (6), and contrasted with the response of the PepMoV strain from California, which induced local lesions in Chenopodium amaranticolor (6).

ELISA results indicated the presence of TEV and PVY in pepper and weed samples, however, not all plants were tested for these viruses. In 1992, both viruses were detected in peppers collected from Deming and Las Cruces, NM, and in 
1993, both viruses were detected from Deming. In 1992 and 1993, TEV and PVY were detected from $S$. elaeagnifolium and C. arvensis, while in 1992, the viruses were detected from these two weed hosts and from Chamysuraces sp. and Physalis wrightii.

All 14 pepper samples and one weed sample (D. innoxia) tested positive for PepMoV using monoclonal antibodies. The results for two of the pepper samples analyzed using monoclonal antibodies indicated the presence of variability among the PepMoV isolates and the presence of other potyviruses in the pepper samples.

Pepper samples collected in 1993 near alfalfa fields gave positive ELISA results for AlMV (data not shown). A few pepper samples showed symptoms characteristic of those caused by TSWV such as chlorotic concentric rings on pods and leaves, but they were not assayed for that virus. In addition, stunted peppers were found with curled leaves characteristic of infection with Beet curly top virus, but no confirmatory analyses were conducted. Peppers not showing viral symptoms were not positive using ELISA for any virus tested.

Pepper plants showing a range of viral symptoms were observed during our field sampling. The most common viral symptoms observed were distorted fruit with uneven color and distorted foliage with mosaic or mild mottle. PepMoV was con- sistently detected in pepper plants showing these symptoms, suggesting it had an active role in causing these symptoms. Other symptoms could have been caused by other viruses or by synergistic interactions among the viruses. PepMoV appears to have been the most significant factor in the 1992 to 1993 viral epidemic of pepper in southern New Mexico.

The presence of PepMoV in common perennial and annual weeds found near pepper fields and the yearly cultivation of susceptible chile plants suggest that the virus might continue to impact chile production. PepMoV continues to be detected infecting chile in southern New Mexico fields each year, although the incidence is considerably less than epidemic.

\section{ACKNOWLEDGMENTS}

We thank Marvin Clary (Deming, NM) for his help in the collection of samples and identification of plant samples and Richard D. Lee (Extension Weed Specialist, New Mexico Cooperative Extension) for the identification of some plant samples. Funding for this study was provided by Border Foods, Inc., Deming, NM, Mountain Pass Canning (PET Incorporated), Anthony, TX, and the New Mexico State University Agricultural Experiment Station.

\section{LITERATURE CITED}

1. Abdalla, O. A., Desjardins, P. R., and Dodds, J. A. 1991. Identification, disease incidence, and distribution of viruses infecting peppers in California. Plant Dis. 75:1019-1023.

2. Ball, E. M., Hampton, R. O., De Boer, S. H., and Schaad, N. W. 1990. Polyclonal Antibodies. Pages 33-54 in: Serological Methods for Detection and Identification of Viral and Bacterial Plant Pathogens. R. Hampton, E. Ball, and S. De Boer, eds. American Phytopathological Society St. Paul, MN.

3. Benner, C. P., Kuhn, C. W., Demski, J. W., Dobson, J. W., Colditz, P., and Nutter, F. W. 1985. Identification and incidence of pepper viruses in northeastern Georgia. Plant Dis. 69:999-1001.

4. Lommel, S. A., McCain, A. H., and Morris, J. T. 1982. Evaluation of indirect enzyme-linked immunosorbent assay for the detection of plant viruses. Phytopathology 72:1018-1022.

5. Muhyi, R. I., and Bosland, P. W. 1989. A survey identifying pepper iruses occurring in southern New Mexico. HortScience 24:93.

6. Nelson, M. R., and Wheeler, R. E. 1978. Biological and serological characterization and separation of potyvirus that infect peppers. Phytopathology 68:979-984.

7. Nelson, M. R., Wheeler, R. E., and Zitter, T. A. 1982. Pepper mottle virus. CMI/AAB Descriptions of Plant Viruses No. 253.

8. Rodriguez-Alvarado, G., Kurath, G., and Dodds, J. A. 1995. Heterogeneity in pepper isolates of cucumber mosaic virus. Plant Dis. 79:450-455.

9. Sherwood, J. L., Reddick, B. B., and Conway, K. E. 1988. Reactions of Bahamian hot chile to single and double infections with tobacco mosaic virus and potato virus Y. Plant Dis. 72:14-16.

10. Villalon, B. 1975. Virus diseases of bell peppers in south Texas. Plant Dis. Rep. 59:858862.

11. Zitter, T. A. 1973. Further pepper virus identification and distribution studies in Florida. Plant Dis. Rep. 57:991-994. 